\title{
RASIONALITAS PETANI DALAM MERESPONS PERUBAHAN KELEMBAGAAN PENGUASAAN LAHAN DAN SISTEM PANEN PADA USAHATANI PADI
}

\author{
Farmers Rationality in Responding Institutional Change of Land Tenure \\ and Harvest System of Rice Farming
}

\author{
M. Saleh S. Ali ${ }^{1 *}$, Awaluddin Yunus ${ }^{2}$, Darmawan Salman ${ }^{1}$, \\ Eymal B. Demmallino ${ }^{1}$ \\ 1Program Studi Agribisnis, Departemen Sosial Ekonomi Pertanian, \\ Fakultas Pertanian, Universitas Hasanuddin, Makassar \\ 2Program Studi Agribisnis, Jurusan Sosial Ekonomi Pertanian, \\ Fakultas Pertanian, Universitas Islam Makassar, Makassar \\ *Kontak penulis: saleh.assofie@agri.unhas.ac.id
}

\begin{abstract}
Basically human are rational beings that always consider the principle of efficiency and effectiveness in performing every action. They will always tend to maximize their rationality. This study aims to analyze the rationality of farmers in responding to institutional changes in rice farming, especially in the procurement of agricultural land and harvest. The paradigm used is postpositives, with a single case study focusing on farmers ' rational and agricultural institutional changes in response to the institutional change. This research conducted in Bonto Marannu Village, Lau District, Maros Regency, South Sulawesi. The data were analyzed descriptively qualitatively, by comparing between the time of institutional change before and after the use of superior seeds of rice farmers. Informants were from farmers ' households, and related actors determined by snowballs/a snowball/the snowball sampling technique. The results showed changes in the rationality of farmers associated with changes in agricultural institutions. If the farmers in the process of production, formerly practice mutual assistance through barter transactions, have transformed into transactions in the form of wages, and differentiation in the community of paddy farmers into agricultural labor, professional labor, farm managers, and entrepreneur farmers as owners capital, as a transition of feudalism to capitalism. This study concludes that farmers have responded to institutional and land-harvesting changes in rational instrumental through innovative and technological developments and has deregulated subsistence roots into commercial-based market economies.
\end{abstract}

Keywords: farmers; rationality; institutional change; rice farming.

Sitasi: Ali, M.S.S., A. Yunus, D. Salman, E.B. Demmallino, 2018. Rasionalitas Petani dalam Merespons Perubahan Kelembagaan Penguasaan Lahan dan Panen pada Usahatani Padi, JSEP 14(1): 1 - 14.

\section{Pendahuluan}

Pada dasarnya manusia termasuk petani adalah mahluk rasional yang selalu mempertimbangkan prinsip efesiensi dan efektifitas dalam melakukan setiap tindakan. Menurut Mosher (1991), petani adalah manusia yang berpikir dan bekerja untuk mendapatkan tujuan hidupnya yang merdeka tanpa tekanan dari pihak 
manapun. Mereka mempunyai kemampuan bukan saja sebagai juru tani tetapi juga mempunyai kemampuan sebagai manajer. Dalam mengelola usahatanianya petani akan selalu memaksimalkan rasionalitasnya dan selalu cendrung menghitung nilai sesuatu (utility) yang hendak dipertukarkan (Waters, 1994). Popkin (1979) menyebutkan bahwa petani adalah manusia-manusia rasional, kreatif dan juga ingin maju dan menjadi orang kaya. Namun, petani tidak mempunyai kesempatan untuk itu karena ketidakmampuannya mengakses pasar untuk menjual hasil pertaniannya sendiri ke pasar. Tetapi menurut Scott (1981) rasionalitas petani adalah persoalan moral ekonomi petani yang harus berjuang hidup di garis batas subsistensi. Petani akan menggunakan konsep "dahulukan selamat" sebagai pilihan, ketika mereka diperhadapkan dalam mengambil resiko, dan pilihan itu menurut Scott adalah pilihan rasional.

Di sisi lain, Hayami dan Kikuchi (1987), tidak membantah Scott maupun Popkin, tetapi menyatakan bahwa kecenderungan masyarakat petani pada dasarnya adalah saling tolong menolong dalam memenuhi kebutuhan subsistensinya. Pandangan ini senada dengan Boeke (1974), bahwa perkembangan masyarakat lebih bersifat sosial daripada ekonomi. Boeke memperkenalkan rasionalitas petani melalui pemahaman nilai dan sikap masyarakat petani sebagai limited needs atau oriental misticism yakni suatu sikap merasa puas, tenteram, damai tanpa harus "memaksakan" keinginan lebih daripada yang mereka miliki. Disisi lain Gertz (1968), melihat fenomena shared poverty mengandung aspek moral dan rasional dalam menjaga ikatan solidaritas dan kekeluargaan yang kuat di desa, dan hal ini secara empirik diakui sebagai salah satu faktor peredam potensi perlawanan sosial petani. Martinussen (1997) menyebutkan bahwa kebanyakan peneliti Barat melihat petani di negara dunia ketiga sebagai irasional karena mereka tidak mempertimbangkan dan mengeksploitasi semua kesempatan-kesempatan yang ada untuk meningkatkan produksi dan pendapatannya. Petani subsisten disebut sebagai irasional, karena hanya berproduksi untuk diri dan keluarganya saja.

Introduksi teknologi pertanian di Indonesia yang telah digencarkan dalam 40 tahun terahir melalui revolusi hijau mendorong perubahan kelembagaan usahatani padi. Usahatani padi yang sebelumnya dikelola secara subsisten oleh petani dalam rumah tangganya telah mengalami perubahan. Kegiatan proses produksi usahatani padi seperti pengadaan dan pengolahan lahan, perbenihan, penanaman, pemeliharaan, pemanenan, pengolahan hasil panen dan pembiayaan, sudah berada di luar penguasaan petani dan rumahtangganya (Yunus et al, 2016; Yunus, 2017). Gambaran perubahan kelembagaan tersebut menunjukkan bahwa petani dituntut untuk meningkatkan kapasitasnya, agar perubahan kelembagaan tidak menjadi ancaman bagi mereka.

Merujuk dari berbagai pengertian yang dikemukakan Ruttan dan Hayami (1984), Ostrom (1985), Williamson, (1985), Uphoff (1986), Nabli dan Nugent, (1989) dan North, (1990), maka yang dimaksud kelembagaan adalah: suatu tatanan dan pola hubungan antara anggota masyarakat atau organisasi yang saling mengikat yang dapat menentukan bentuk hubungan antar manusia atau antar organisasi yang diwadahi atau tidak diwadahi dalam suatu organisasi atau jaringan dan ditentukan oleh faktor-faktor pembatas dan pengikat berupa norma, kode etik aturan formal maupun informal untuk mengendalikan perilaku sosial serta insentif untuk bekerjasama dan mencapai tujuan bersama. 
Penelitian kelembagaan pertanian telah banyak dilakukan, antara lain: Transformasi Kelembagaan Tradisional Untuk Menunjang Ekonomi Kerakyatan di Pedesaan (Saptana, et al, 2003), Ekonomi Kelembagaan Sistem Usahatani Padi di Indonesia (Rachman, et al, 2005), Fenomena Sosiologis Metamorphosis Petani (Elizabeth, 2007), Rancangan Kelembagaan Tani Dalam Implementasi Prima Tani (Hermato, 2007), Status dan Arah Pengembangan Kelembagaan Petani (Suradisastra et al, 2007), Kelembagaan, Kebijakan dan Respon Petani Padi Terhadap Elnino (Dawe, et al, 2008), Akar Kolonial Ketidak Setaraan Lahan (Frankema, 2010), Perubahan Kelembagaan Dan Proteksi Warisan Regional (Jena dan Greote, 2010), Lembaga Dan Organisasi Petani Dalam Pengaruh Negara dan Pasar (Syahyuti, 2010), Partisipasi Dan Aksi Kolektif Anggota Koperasi Petani (Gedara, et al, 2012), Relasi Anggota Koperasi Pertanian: Implikasi dan Komitmen (Cechin, et al, 2013), Refleksi Perubahan Pertanian: Pentingnya "Pertuantanahan" (Harriss, 2013), Penggunaan Partisipatif Farmer Groups Model Transfer Teknologi Pertanian (Kadigi, 2013), Karakteristik Modal dan Pembiayaan Produksi Pertanian (Mondelli, et al, 2013), Meningkatkan Kapasitas Adaptasi Petani Padi Skala Kecil (Peñalba, 2013), Dekontestualisasi Pengetahuan, Situasi Politik: Pengetahuan Baru-Politik Lokal Sumberdaya Genetik Padi (Srang-iam, 2013), Dari Pertanian Untuk Pembangunan: Koalisi Urban (Sami, 2013) dan sebagainya.

Kajian kelembagaan pertanian yang telah dilakukan itu telah memberikan kontribusi yang besar terhadap perkembangan kelembagaan pertanian. Kajian kelembagaan tersebut juga telah memperkaya kajian sosial ekonomi pertanian, membantu pemerintah dalam pengambilan kebijakan dan mengimplementasikannya dalam berbagai program pembangunan pertanian yang bertujuan meningkatkan produksi usahatani dan kesejahteraan petani di pedesaan. Berangkat dari terjadinya proses perubahaan kelembagaan terutama pada usaha pertanian padi yang sedang berlangsung pada masyarakat tani, maka penelitian ini bertujuan untuk mengkaji bagaimana dinamika petani dalam merespon perubahan kelembagaan terutama dalam penguasaan lahan dan panen.

\section{Metode Penelitian}

Penelitian ini menggunakan pendekatan kualitatif yang dilaksanakan pada komunitas petani padi di Desa Bonto Marannu, Kecamatan Lau, Kabupaten Maros, Sulawesi Selatan. Desa Bonto Marannu berjarak kurang lebih dua km dari ibukota kecamatan dan kurang lebih enam km dari ibukota kabupaten. Desa ini merupakan dataran rendah dengan luas 590,10 hektar yang terletak pada ketinggian 0 - 7 meter dari permukaan laut dengan curah hujan $1.848 \mathrm{~mm} /$ tahun dan suhu rata-rata $29-30^{\circ} \mathrm{C}$ yang sangat cocok untuk pertumbuhan tanaman padi.

Data penelitian diperoleh dari informan yang dipilih secara sengaja (purposive) yaitu informan kunci yang dianggap mengetahui banyak mengenai kelembagaan usahatani padi dan kehidupan petani padi. Informan yang diwawancarai yaitu lima orang petani sekaligus tokoh masyarakat, tiga orang petani pengurus kelompok tani, tiga orang petani yang mempunyai penggilingan dan hand traktor; seorang petani yang mempunyai penggilingan, hand traktor dan mobil panen (combine harvester); dan lima orang petani pemilik penggarap. Selainnya adalah petugas penyuluh dan pejabat Dinas Pertanian Kabupaten Maros. 
Data dianalisis secara kualitatif dengan mengkomparasikan perubahan kelembagaan usahatani padi sebelum dan sesudah penggunaan benih unggul. Sementara respon petani terhadap perubahan kelembagaan usahatani padi dianalisis berdasarkan tindakan petani pada proses kegiatan pengadaan lahan dan pemanenan.

\section{Hasil dan Pembahasan}

\section{a. Perubahan Kelembagaan Usahatani Padi}

\section{Perubahan Kelembagaan Penguasaan Tanah}

Penguasaan lahan garapan menentukan status seseorang di dalam masyarakat tani. Status tersebut dikenal sebagai: (a) tuan tanah yaitu orang yang memiliki tanah tetapi tidak menggarapnya melainkan memberikannya kepada orang lain untuk menggarapnya; (b) petani pemilik yaitu petani yang hanya menggarap lahan miliknya sendiri; (c) petani penggarap atau penyakap yaitu petani yang menggarap lahan orang lain dengan sistem bagi hasil; (d) petani pemilik penggarap yaitu petani yang disamping memiliki lahan sendiri juga menggarap lahan orang lain dengan sistem bagi hasil; (e) petani gadai yaitu petani yang menggarap lahan yang digadainya; (f) petani penyewa adalah petani yang menyewa lahan orang lain untuk periode tertentu; dan (g) buruh tani yaitu orang yang terlibat dalam aktivitas pertanian melalui upah.

Terdapat beberapa cara seorang petani memperoleh lahan garapan, yaitu melalui warisan orang tua, jual beli, bagi hasil (tesang tanah), menggadai, dan menyewa lahan sawah. Pengadaan lahan garapan melalui proses pembelian sekarang lebih sulit dibandingkan sebelum tahun 1970an saat petani masih menanam bibit lokal. Dulu pembelian lahan lebih mudah karena lahan cukup tersedia dan cukup luas untuk diperjual belikan. Keadaan lahan waktu itu masih tadah hujan dengan pola tanam hanya sekali setahun. Harga lahan waktu itu masih relatif murah yang dinilai antara 10-15 koin emas (ringgit mekkah) per hektar (satu koin setara dengan 31,6 gram emas 23 karat). Umumnya transaksi pembayaran lahan dalam bentuk koin emas.

Pengadaan lahan sawah melalui gadai adalah suatu proses perpindahan hak penggarapan lahan dari pemilik lahan (penggadai) karena membutuhkan sejumlah uang kepada orang yang mempunyai uang (penerima gadai). Besarnya nilai gadai bergantung pada kebutuhan penggadai dan kemampuan keuangan pemegang gadai, serta luas lahan yang akan digadaikan. Transaksi gadai selalu dalam bentuk koin emas atau gabah yang harus dikembalikan dengan jumlah yang sama oleh penggadai kepada penerima gadai pada saat lahan ditebus. Walaupun pembayaran bisa dilakukan dalam bentuk uang rupiah tapi nilai transaksi selalu dalam bentuk koin emas atau gabah. Selama masa gadai, hasil lahan (sawah) diambil sepenuhnya oleh pemegang gadai. Pemegang gadai mempunyai beberapa pilihan terhadap lahan gadainya, yaitu menggarapnya sendiri, menyakapkannya kepada petani lain, atau mempersewakannya kepada orang lain dengan sepengetahuan pemilik lahan, tetapi tidak boleh menggadaikannya kembali atau menjualnya ke pihak lain.

Penyakapan adalah proses pengalihan penggarapan dari pemilik lahan kepada penyakap yang akan menggarap lahan dengan sistim bagi hasil. Antara pemilik dan penyakap biasanya mempunyai hubungan keluarga, bertetangga, pertemanan, sekampung, hubungan bisnis (gadai). 
Terdapat aturan pembiayaan dan sistim bagi hasil yang harus dipatuhi. Pembiayaan biasanya terlebih dahulu ditanggulangi oleh penyakap dan akan diperhitungkan setelah panen. Ada beberapa bentuk pengaturan pembiayaan yaitu: a) seluruh biaya ditanggung bersama atau dibagi dua; b) pemilik lahan menanggung sarana produksi (benih, pupuk, dan obat-obatan) dan pajak lahan, sedangkan penyakap menanggung biaya pengolahan tanah, biaya irigasi dan biaya penanaman sedangkan biaya panen ditanggung masing-masing; c) pemilik lahan menanggung biaya sarana produksi dan membantu sebagian biaya traktor dan biaya tanam, dan biaya panen ditanggung masing-masing. Terdapat dua cara bagi hasil yaitu: pertama penyakap diberikan kepercayaan sepenuhnya oleh pemilik lahan melakukan pembagian hasil panen, setelah panen penyakap mengeluarkan seluruh biaya yang belum dibayarkan oleh pemilik lahan kemudian hasilnya dibagi dua; kedua menjelang panen penyakap membagi dua padi siap panen di lahan sawah (masese) dan mempersilahkan pemilik lahan terlebih dahulu memilih bagian mana yang disukai, kemudian masing-masing memanen bagiannya atau pemilik lahan meminta bantuan penyakap untuk dipanenkan bagiannya sesuai dengan biaya yang berlaku.

Pengadaan lahan garapan dengan cara menyewa lahan mulai muncul sejak usahatani padi menggunakan benih unggul dan berubahnya sistim panen dari panen potong (ani-ani) ke panen sistim tebas (sabit) dengan perontokan. Tuan tanah baik yang tinggal di desa maupun yang tinggal di kota atau di daerah lain lebih menyukai menyewakan lahan sawahnya yang ada di desa ke petani penggarap dibanding sistim sakap. Dengan menyewakan lahan, petani pemilik lahan mempunyai kepastian hasil lahannya berupa uang sewa yang sudah ditetapkan. Dari sisi penyewa keuntungannya adalah adanya kepastian biaya tetap usahatani berupa uang sewa serta memudahkan petani dalam pengambilan keputusan terhadap keseluruhan kegiatan usahatani karena tidak perlu lagi melibatkan pemilik lahan. Umumnya jangka waktu yang disepakati dalam hal penyewaan lahan adalah minimal satu tahun. Cara pembayaran uang sewa dilakukan didepan atau sebelum penggarapan lahan dimulai.

Kelembagaan pengadaan lahan secara bertahap mengalami perubahan seiring dengan semakin berkembangnya pengetahuan, penggunaan teknologi, dan keterampilan petani dalam berusahatani. Sebelum tahun 1970 pada saat petani masih menanam padi lokal dengan penggunaan teknologi yang masih sederhana dengan kecendrungan berusahatani secara subsisten, umumnya petani memperoleh lahan garapan relatif mudah dengan sistim sakap dan gadai. Setelah petani menanam benih unggul dan menggunakan teknologi modern serta semakin bertambahnya petani yang memerlukan lahan garapan mulailah terasa adanya keterbatasan sumberdaya lahan. Petani mulai merasakan persaingan dalam memperoleh lahan garapan dan menyadari adanya nilai atau biaya terhadap lahan. Muncullah penyewaan lahan garapan sebagai kelembagaan pengadaan lahan yang baru. Pengadaan lahan garapan usahatani baik melalui pembelian lahan, sakap, gadai, dan sewa sudah mengarah kepada komersialisasi, sehingga sumberdaya lahan dalam berusahatani menjadi salah satu elemen biaya yang diperhitungkan petani. 


\section{Perubahan Kelembagaan Panen}

Kelembagaan panen berkembang seiring dengan perkembangan teknologi budidaya pertanian. Pada saat petani masih menanam padi lokal dengan sistem potong padi dengan ani-ani pemanenan dilakukan oleh petani dan anggota keluarganya atau saling membantu dengan tetangga di desa. Lembaga pemanenan padi mulai berubah ketika petani menanam padi unggul yang karakteristik fisiknya masih seperti padi lokal dengan produksi lebih tinggi dari padi lokal sebelumnya (1970 - 1980). Pemanenan padi mulai membutuhkan tenaga kerja yang banyak dari luar rumahtangga dengan sistim upah menggatikan sistim panen saling membantu. Tenaga kerja pemanen (pakattu) diupah dengan cara memberikan bagian padi dari hasil panennya, yaitu lima ikat (kawerang) keluar satu satu ikat (kawerang), tidak ditanggung makan dan pemondokan. Untuk pemanen dari luar desa, aturannya enam ikat keluar satu ikat, ditanggung akomodasi dan konsumsi oleh pemilik lahan. kewajiban pemanen lainnya adalah mengangkut hasil panen ke rumah pemilik lahan. Pemanen dan aturan upah panen diterangkan oleh seorang informan berikut.

"Dulu padi lokal dipanen oleh petani dan anggota rumahtangga atau dipanen bersama-sama dengan keluarga dan tetangga, belum ada pemanen upahan. Perkembangan panen mulai sejak adanya padi unggul tetapi masih panen sistim potong, petani mulai memakai jasa pemanen, dengan upah panen yang berlaku kesepakati petani di desa, umumnya 6:1 ditanggung makan dan pemondokannya, jika tidak ditanggung 5:1. Ketika musim panen tiba banyak keluarga yang tidak mampu dari kota atau saudara dan kemanakan yang kurang mampu yang tinggal di desa dipanggil panen padi, setelah diberikan bagian sesuai pembagian yang berlaku, diberi lagi tambahan, atau dibagi dua saja hasil panennya"

(Wawancara $A b, 62$ tahun).

Pemanen dalam jumlah terbatas biasanya mempunyai hubungan kekerabatan yang masih dekat dengan petani, biasanya upah panennya tiga keluar satu atau dibagi dua saja. Walaupun pemanenan padi sudah bergeser ke sistem upah, hubungan kekerabatan, pertetanggaan, dan perasaan senasib masih kental pada masyarakat desa sehingga upah panen kadang-kadang tidak terlalu ketat. Pemanen selain memotong padi, juga bertugas mengangkut hasil panen dari sawah ke rumah petani.

Perubahan panen padi dari sistim potong ke sistim tebas terjadi seiring dengan penanaman padi unggul baru yang sudah tersebar luas ditanam petani pada awal tahun 1980-an. Padi unggul baru ini, batang dan malainya pendek, berumur pendek, dan mudah rontok dengan potensi produksi lebih tinggi dari benih padi sebelumnya, sehingga petani dapat menanamnya dua kali setahun. Karakteristik tersebut, mengubah sistem panen potong menjadi sistem panen tebas. Perkembangan sistem panen tebas sendiri mengalami perkembangan pesat mulai dari panen tebas dengan prontok manual, panen tebas dengan mesin perontok, hingga panen dengan munggunakan mobil panen (combine harvester). Perkembangan lembaga pemanenan mengikuti perkembangan teknologi panen tersebut.

Pada awal sistem pemanenan dengan sabit masih menggunakan perontok manual yang dilakukan oleh petani dan anggota rumahtangganya dan atau pemanen (pasangki) upahan dengan sistim upah bagi hasil panen. Pemanenan sistim tebas terdiri dari kegiatan menebas, mengumpulkan tebasan, merontokan secara manual, mengarungkan dan pengangkutan hasil ke rumah petani, sehingga 
pemanenan dilakukan secara berkelompok oleh pemanen untuk mempercepat proses pemanenan. Kegiatan-kegiatan dalam proses pemanenan dilakukan secara bergantian oleh anggota kelompok pemanen, sehingga upah panen umumnya dibagi rata kepada semua anggota. Aturan pembagian antara pemilik lahan dengan kelompok pemanen (pasangki) untuk pemanen upahan (pasangki passaro) adalah $4: 1$ tidak ditanggung makan atau 5 : 1 untuk yang ditanggung makan.

Perkembangan teknologi perontokan pada panen tebas dengan penggunaan mesin perontok relatif belum mengubah sistem kerja, pemanenan tetap membutuhkan banyak tenaga pemanen untuk menebas, mengumpulkan tebasan, merontokan, mengarungkan, dan mengangkut hasil panen. Dengan penggunaan mesin perontok (power threser) dapat mempercepat perontokan padi, sehingga waktu pemanenan lebih cepat dari cara perontokan manual. Perubahan yang terjadi adalah semakin murahnya upah panen, yaitu menjadi 6:1 tidak ditanggung makan. Kelompok pemanen membagikan kepada anggotanya secara merata setelah mengeluarkan seluruh biaya kerja saat pemanenan seperti biaya konsumsi dan transpor, jika harus bermalam di lokasi panen biasanya akomodasi memperoleh tumpangan gratis oleh petani. Perubahan ini, membuat pemanenan lebih efektif dan efisien dibandingkan dengan sistim panen sebelumnya.

Setelah sistim panen tebas dengan mesin perontok padi (power threser) teknologi pemanenan padi mengalami perkembangan dengan digunakannya mobil pemanen (combine harvester) yang memadukan penebasan dengan perontokan padi. Teknologi panen ini, mengubah kelembagaan pemanenan dari kelompok pemanen yang digantikan oleh mesin panen, mengubah sistem kerja, mengubah aturan panen, dan relasi petani. Sistem kerja mobil panen bertumpu pada pengunaan teknologi yang padat modal, menggantikan sistem kerja panen tebas dengan perontok mesin (power threser) yang bertumpu pada padat karya dengan teknologi yang murah dimana mesin tersebut masih bisa dibuat atau dimodifikasi oleh petani atau kelompok pemanen.

Penggunaan mobil panen membuat pengelolaan panen keluar dari rumahtangga petani. Sebagian besar petani menggunakan jasa mobil panen, dan hanya sebagian kecil lainnya yang tetap menggunakan cara panen tebas dengan perontok manual atau dengan perontok mesin karena alasan teknis dan sosial. Alasan teknis lahan sawah tergenang air dengan lumpur dalam atau tidak ada jalan sehingga tidak terjangkau mobil panen.

Penyedia jasa mobil panen di lokasi penelitian pada saat penelitian hanya ada satu orang, karena membutuhkan modal besar. Untuk memenuhi kebutuhan petani terhadap jasa mobil panen petani tidak mengalami kesulitan karena penyedia jasa mobil panen cukup banyak tersedia di tetangga desa atau dari daerah lainnya. Dengan banyaknya penyedia jasa mobil panen yang saling bersaing dengan cara meningkatkan pelayanan dan menawarkan upah panen yang murah menguntungkan petani pengguna jasa panen.

Aturan panen yang disepakati antara pemilik sawah dengan penyedia jasa mobil panen adalah penyedia jasa panen menanggung karung, dengan pembagian setiap 11:1 karung gabah, petani memperoleh bagian 10 karung dan satu karung bagian jasa panen. Pemilik mobil panen yang mempekerjakan operator mobil panen membayar upah Rp. 5.000,- setiap karungnya. Sementara operator mempekerjakan 3-4 orang tenaga kerja pembantu, yang dibayar secara harian atau secara 
proporsional sesuai jumlah upah yang diperoleh oleh operator panen per harinya. Penggunaan mobil panen dan aturan-aturanya dijelaskan oleh petani sekaligus pemilik pemilik mobil panen dan penggilingan berikut.

"Pada awalnya mobil panen yang beroperasi di desa ini berasal dari daerah lain, waktu itu upah mobil panen masih 9 karung keluar 1 karung dan petani menanggung karung, waktu itu penggunaannya diprotes oleh petani kecil dan buruh tani. Setelah petani merasakan keunggulan mobil panen berupa upah yang murah dan cepat, 3 tahun terakhir sudah ramai digunakan petani. Saya sendiri membeli mobil panen tahun 2015 dan menambah 1 unit lagi tahun 2016 ini, tetapi yang beroperasi di desa ini banyak juga dari desa atau daerah lain, karena sudah banyak yang beroperasi maka sewa mobil panen juga semakin murah, sekarang sewa yang berlaku 11 karung keluar satu karung, bahkan sudah ada yang 12 karung keluar 1 karung dan mobil panen menanggung karung. Sementara upah operator dan tenaga kerja pembantunya yang terdiri dari $3-4$ orang memperoleh upah kerja Rp.5.000,- setiap karungnya dari upah mobil panen"

(Wawancara Dg. L, 54 tahun)

Hubungan petani juga mengalami perubahan dengan perkembangan teknologi panen dan kelembagaan pemanenan. Sebelumnya petani berhubungan dengan banyak pemanen tetapi dengan penggunaan mesin panen, petani hanya berhubungan dengan penyedia jasa panen dengan sifat hubungan bisnis yang lebih komersial. Penggunaan mobil panen juga menciptakan kelompok pekerja baru antara petani pemilik gabah dengan kelompok pengangkut gabah yang lebih komersil, dengan upah pengangkutan antara Rp. 5.000,- sampai Rp. 15.000,- per karung, tergantung jarak dan besar karung.

Pemanenan dengan menggunakan jasa mobil panen bagi petani lebih efektif dan efisien dibandingkan dengan sistim panen sebelumnya. Efektifitas pemanenan, dari segi waktu hanya membutuhkan waktu 2-4 jam per hektar sebelumnya masih butuh 2-3 hari, dan dari segi pekerjaan petani tinggal menghitung karung hasil kerja mobil panen, mereka tidak sibuk lagi mengontrol kelompok pemanen mulai dari proses panen hingga membagi hasil panen. Efisiensi penggunaan mobil panen juga semakin menguntungkan petani, yang diperoleh dari tingkat kehilangan hasil panen yang rendah, dan upah panen yang semakin murah.

\section{b. Rasionalitas Petani dalam Merespons Perubahan Kelembagaan}

Perubahan kelembagaan usahatani padi menjadi arena pertarungan antara pengetahuan yang bekerja secara diam-diam (tacit knowledge) dari lokalitas pengetahuan (indigenous knowledge) petani dengan pengetahuan dan teknologi modern yang dipaksakan (coercive) oleh pemerintah. Hasil pertarungan itu telah mendorong perubahan kelembagaan pertanian padi ke arah yang lebih efektif dan efisien. Perubahan tersebut direspon oleh petani melalui tindakan rasional. Menurut Weber, terdapat empat tindakan sosial, yaitu tindakan rasional instrumental (instrument-rational action), tindakan rasional berdasarkan nilai (valuerational action), tindakan emosional (afektif), dan tindakan tradisional (Turner, 2012). Tindakan rasional yang bersifat instrumental adalah tindakan yang ditujukan pada pencapaian tujuan yang secara rasional diperhitungkan dan diupayakan sendiri oleh aktor petani. Tindakan rasional berdasarkan nilai (value) adalah tindakan yang 
dilakukan untuk alasan dan tujuan yang berkaitan dengan nilai yang diyakini petani tanpa memperhitungkan prospek yang berkaitan dengan berhasil atau gagalnya tindakan dalam berusahatani padi. Tindakan emosional (afektif), yaitu tindakan yang ditentukan oleh kondisi dan orientasi emosional petani, ketika pilihan ditentukan oleh adanya emosi yang kuat seperti tindakan marah, kesedihan atau putus asa, perasaan cinta dan kasih sayang. Tindakan tradisional (tindakan berdasarkan kebiasaan) adalah tindakan ketika pilihan ditentukan oleh keakraban dan kebiasaan yang sudah mengakar secara turun menurun yang dilakukan petani.

Respon rasionalitas petani dalam kegiatan usahatani padi dapat dicermati pada tindakan petani dalam berbagai pengambilan keputusan pengelolaan sumberdaya dan aktivitas dalam proses produksi. Tindakan rasionalitas petani dalam penelitian ini hanya dibatasi dalam pengadaan lahan dan pemanenan. Pengelolaan sumberdaya dan aktivitas usahatani padi yang dulunya berada dalam rumahtangga petani mengalami perubahan, dimana sumberdaya dan aktivitas usahatani tidak lagi dikuasai sepenuhnya oleh rumah tangga petani, sehingga tersedia alternatif-alternatif pilihan di luar rumahtangganya. Dengan perubahan kelembagaan usahatani tersebut, petani meresponnya dengan tindakan rasional.

\section{Rasionalitas Petani dalam Mersepons Perubahan Kelembagaan Penguasaan Lahan}

Dinamika dalam pengadaan lahan usahatani dapat ditelusuri dari tindakantindakan petani mengadakan lahan garapan. Alternative-alternative yang tersedia bagi petani untuk memperoleh lahan garapan, yaitu melalui lembaga sakap lahan (bagi hasil), gadai (menerima lahan gadai), sewa, jual beli, warisan dan mahar (pemberian lahan kepada pihak isteri sebelum akad nikah dilakukan). Tindakan petani memperoleh lahan garapan melalui menyakap lahan, memegang lahan gadai, menyewa lahan, dan membeli lahan merupakan respon rasional petani yang bersifat rasional instrumental yang berorientasi tujuan dan nilai. Sementara lahan garapan yang melalui warisan dan mahar merupakan respon rasional petani yang bersifat tradisional, dan tindakan ini sudah semakin ditinggalkan oleh komunitas petani. Respon petani dalam pengadaan lahan garapan pada usahatani padi dapat dilihat pada Tabel 1.

Tabel 1

Respons Rasionalitas Petani dalam Pengadaan Lahan Garapan

\begin{tabular}{clcccc}
\hline \multirow{2}{*}{ No. Uraian Pengadaan Lahan } & \multicolumn{3}{c}{ Respon Petani } \\
\cline { 3 - 5 } & & Instrument & Nilai & Emosi & Tradisi \\
\hline 1 & Lahan sakap (bagi-hasil) & $\sqrt{ }$ & & $\sqrt{ }$ \\
2 & Lahan gadai (pemegang gadai) & $\sqrt{ }$ & & & $\sqrt{ }$ \\
3 & Sewa lahan & $\sqrt{ }$ & $\sqrt{ }$ & & \\
4 & Beli lahan & $\sqrt{ }$ & & $\sqrt{ }$ & $\sqrt{ }$ \\
5 & Lahan warisan & & & $\sqrt{ }$ & $\sqrt{ }$ \\
6 & Lahan mahar (perkawinan) & & &
\end{tabular}

Tindakan petani dalam pengadaan lahan garapan dengan menyakap dan gadai adalah tindakan rasionalitas instrumental yang bertujuan untuk memperoleh keuntungan ekonomi. Tindakan ini pada awalnya adalah tindakan tradisional karena sudah menjadi kebiasaan petani yang mentradisi dan melembaga dari dulu sejak nenek moyang mereka, yang bernilai sosial karena dilandasi kerjasama saling 
membantu antara petani di dalam komunitasnya. Walaupun kedua tindakan ini bersifat tradisional, tetapi tindakan rasional petani yang bertujuan keuntungan ekonomi semakin dikedepankan dengan memperhitungkan biaya-biaya dan modal finansial serta keuntungan yang akan diperoleh dari lahan garapan tersebut. Ciri tindakan tradisional yang bersifat sosial masih dapat dilihat dari petani yang menggarap lahan sakap dimana petani penggarap belum mempersoalkan biaya jasa dan tenaga kerja yang semakin mahal, dan pada lahan gadai adalah petani pemegang gadai meminjamkan sejumlah uang (patokan emas) untuk membantu pemilik lahan dan hak penggarapan dikembalikan ke penggadai (pemilik lahan) dengan sistim sakap. Namun tindakan tujuan sosial ini semakin tercerabut seiring dengan perkembangan usahatani padi yang menuntut efisiensi.

Tindakan petani dalam pengadaan lahan garapan dengan menyewa lahan dan membeli lahan bertujuan untuk memperoleh keuntungan ekonomi. Kedua tindakan tersebut, berdasarkan pertimbangan untung rugi untuk memutuskan apakah biaya sewa lahan atau investasi modal finansial untuk memperoleh lahan dapat memberikan keuntungan yang memuaskan atau nilai modal bertambah atau dalam kurun waktu tertentu dapat mengembalikan investasi. Dalam proses petani memutuskan tindakan menyewa lahan atau membeli lahan dapat pula dikategorikan tindakan evaluatif, dimana petani sebelum mengambil keputusan dilakukan pengumpulan informasi tentang keadaan lahan seperti luas lahan, jarak, produktivitas, status lahan, dan harga sewa atau beli, kemudian memvalidasinya.

Tindakan petani dalam pengadaan lahan garapan melalui warisan dan perkawinan (mahar), merupakan tindakan rasional petani yang bersifat tradisi dan emosional. Lahan sawah yang dimiliki dan digarap petani yang berasal dari warisan orang tua mereka, secara turun temurun merupakan tradisi yang sudah melembaga dalam masyarakat, dengan tata cara pembagian sesuai hukum Islam. Petani sebagai orang tua selalu berusaha menambah luas lahannya yang bertujuan untuk diwariskan kepada keturunannya sebagai wujud kasih sayang terhadap keluarganya. Prestasi sebuah keluarga tani adalah mempunyai lahan milik yang luas sebagai investasi dan sumber pendapatan keluarga, yang akan diwariskan kepada anggota keluarganya. Mewariskan lahan sawah kepada keturunan menjadi tradisi bagi masyarakat tani dibandingkan dengan harta dalam bentuk lain.

Dalam hal pernikahan, petani mengharapkan pernikahan dengan kerabatnya sendiri, selain untuk alasan menjaga kekerabatan juga karena alasan agar sumberdaya ekonomi keluarga terpelihara atau menyatu kembali utamanya lahan sawah. Pemberian mahar dalam bentuk lahan menjadi tradisi dalam pernikahan keluarga tani. Dengan lahan mahar tersebut, rumahtangga anak mempunyai sumber pendapatan sendiri. Pemilikan lahan dari lahan warisan dan lahan mahar sudah mulai ditinggalkan, karena kebanyakan petani tidak ingin anaknya menjadi petani, sehingga lahan sawah digadaikan atau dijual untuk membiayai pendidikan, pernikahan, berhaji, dan untuk modal kerja.

Tindakan mewariskan lahan dan mahar dalam bentuk lahan tersebut sudah tercerabut dari tradisi komunitas petani. Petani tidak lagi mengutamakan lahan sebagai warisan kepada anak, mereka rela kehilangan lahan untuk biaya sekolah dan modal kerja, sebagai pilihan investasi untuk anak. Demikian pula pernikahan (mahar lahan) sudah beralih ke emas dan biaya pernikahan, untuk itu petani menggadaikan atau menjual lahan sawahnya untuk menikahkan anaknya. 


\section{Rasionalitas Petani dalam Merespons Perubahan Kelembagaan Panen}

Perkembangan teknologi panen padi yang diadopsi petani dengan cepat membuat perubahan sosioteknis dan kelembagaan panen. Perubahan tersebut, menyediakan alternatif bagi petani mengambil keputusan dalam kegiatan pemanenan padi. Kondisi yang menjadi pertimbangan petani memutuskan memilih suatu alternatif pada kegiatan pemanenan padi yaitu luas dan keadaan lahan, ketersediaan tenaga kerja panen dalam rumahtangga petani, dan modal peralatan panen. Tindakan rasional petani dalam kegiatan pemanenan disajikan dalam Tabel 2.

Pemanenan padi yang berkembang dari sistim potong (ani-ani) ke sistim tebas dengan perontokan terpisah dan sistim tebas dengan kombinasi perontokan, merubah sosioteknis dan lembaga pemanenan. Respons rasional petani terhadap perubahan tersebut, secara umum petani dapat memilih alternative tindakan yang tersedia yaitu, pemanenan dengan alat manual atau power treser oleh petani dan anggota rumah tangganya, pemanenan dengan power treser oleh kelompok pemanen (paderos), pemanenan dengan combine harvester (mobil panen). Ketiga tindakan respons petani tersebut, dipilih salah satunya oleh petani sesuai dengan kondisi usahataninya.

Pemanenan dengan alat manual atau power treser oleh petani dan anggota rumah tangganya adalah respons petani yang mempunyai lahan sempit dan tenaga kerja dari rumahtangga tersedia. Tindakan tersebut dipilih petani untuk memanfaatkan sumberdaya rumahtangga yang dimilikinya yang bertujuan menghemat biaya panen atau untuk memperoleh hasil panen yang utuh dari lahan garapan yang luasnya terbatas. Tindakan petani memanen sendiri dengan anggota rumahtangganya merupakan tindakan tradisional yang sudah menjadi kebiasaan petani secara turun-temurun. Tindakan itu juga bersifat emosional bagi petani dan anggota rumahtangganya yang didorong oleh rasa cinta dan kasih sayang, sehingga setiap anggota rumahtangga petani dengan sukarela ikut terlibat mengambil peran dalam kegiatan pemanenan. Peran petani dan anggota rumahtangganya dalam memenuhi kebutuhannya dilajutkan dengan menjadi buruh panen pada petani lain.

Tabel 2

Respon Rasionalitas Petani dalam Pemanenan Padi

\begin{tabular}{cccccc}
\hline \multirow{2}{*}{ No. } & Uraian Kegiatan Pemanenan Padi & \multicolumn{3}{c}{ Respon Petani } \\
\cline { 3 - 5 } & Instrument & Nilai & Emosi & Tradisi \\
\hline 1 & $\begin{array}{l}\text { Pemanenan dengan alat manual oleh } \\
\text { petani dan anggota rumah tangganya }\end{array}$ & & & $\sqrt{ }$ & $\sqrt{ }$ \\
2 & $\begin{array}{l}\text { Pemanenan dengan power tresher oleh } \\
\text { kelompok pemanen (paderos) }\end{array}$ & $\sqrt{ }$ & & $\sqrt{ }$ \\
3 & $\begin{array}{l}\text { Pemanenan dengan combine harverter } \\
\text { (mobil panen) }\end{array}$ & $\sqrt{ }$ & & \\
\hline
\end{tabular}

Pemanenan dengan power treser oleh kelompok pemanen menjadi respons petani yang mempunyai lahan garapan yang luas, tenaga kerja dari rumahtangga petani tidak mencukupi, dan mempertimbangkan aspek sosial, sehingga petani memilih menggunakan jasa panen tetangga dan kerabat yang ada di kampungnya. Respon petani tersebut merupakan tindakan tradisonal dimana kebiasaan memanen 
melibatkan tetangga dan kerabat petani sudah menjadi kebiasaan yang turun temurun. Walapun tindakan ini sudah menjadi tradisi petani, tetapi petani mulai mempersyaratkan aturan upah panen yang sama dengan upah pemanen dari luar desa, sehingga tindakan ini merupakan tindakan rasional instrumental yang mengarah kepada efisiensi ekonomi dengan tetap memperhatikan aspek sosial dengan mendahulukan tenaga kerja pemanen yang ada di kampungnya.

Pemanenan dengan mobil panen yang paling banyak dipilih oleh petani, baik petani yang menggarap lahan sempit maupun petani yang menggarap lahan luas. Respon petani terhadap pemanenan dengan mobil panen merupakan respon rasional instrumental yang bertujuan memperoleh keuntungan yang maksimal melalui pemanenan yang efektif dan efisien. Dengan penggunaan mobil panen waktu panen lebih singkat, biaya panen lebih murah, pengawasan lebih mudah, dan kegiatan panen lebih mudah. Atas pertimbangan tersebut petani beralih menggunakan mobil panen, petani kecil dan tetagga petani yang kehilangan pekerjaan pemanenan beralih menjadi buruh angkut dan pasca panen.

\section{Kesimpulan}

Perubahan kelembagaan usahatani padi berlangsung dari subsisten menjadi komersil dan dari penguasaan sumberdaya dan aktifitas rumahtangga menjadi terbuka di luar rumahtangga petani. Perubahan tersebut dipicu oleh inovasi dan teknologi pertanian yang telah membuka peluang kerja dan usaha baru dengan relasi saling terkait dengan usahatani padi. Transaksi dalam pengadaan lahan masih didominasi oleh sistem bagi hasil walaupun sudah muncul transaksi formal menggunakan uang yaitu pengadaan lahan dengan cara gadai dan sewa. Perilaku ekonomi petani sudah mengarah kepada tindakan ekonomi rasional yang mempertimbangkan efektivitas dan efisiensi, sehingga perilaku ekonomi petani dalam berusahatani padi yang dulunya melekat (embeddedness) dalam rumah tangga dan komunitas petani di desa, tercerabut ke luar dari rumahtangga petani dan komunitasnya terutama dalam proses panen.

Rasionalitas petani dapat dilihat dari proses perilaku mereka dalam bertindak untuk kegiatan usahatani padinya. Tindakan petani yang berhubungan dengan usahataninya bersifat rasional instrumental, nilai, emosional dan tradisional. Tindakan instrumental petani dalam prosesnya sesuai dengan aturan dan nilai, yaitu tindakan yang dilakukan berdasarkan aturan logika rasional untuk mencapai tujuan tertentu dalam hal ini efektifitas dan efisiensi. Tindakan emosional petani lebih dominan dilakukan berdasarkan perasaan emosional, hal ini masih dipengaruhi oleh hubungan kekerabatan yang masih kental di komunitas petani padi. Tindakan evaluatif petani berdasarkan evaluasi dari tindakan sebelumnya atau yang sementara berlangsung, hal ini dilakukan untuk memperoleh kebenaran atau validasi, suatu tindakan penyelidikan yang dilakukan dalam hal norma-norma dan kriteria ilmu pengetahuan. Tindakan tradisional petani berhubungan dengan kebiasaan petani yang berlangsung secara turun-temurun dan telah mentradisi di dalam komunitasnya.

\section{Daftar Pustaka}

Boeke, J. H.. 1983. "Memperkenalkan Teori Ekonomi Ganda", dalam Sajogyo (ed), Bunga Rampai Perekonomian Desa. Jakarta: Yayasan Obor dan IPB. 
Elizabeth, 2007. Fenomena Sosiologis Metamorphosis Petani: Ke Arah Keberpihakan Pada Masyarakat Petani di Pedesaan Yang Terpinggirkan Terkait Konsep Ekonomi Kerakyatan". Forum Penelitian Agro Ekonomi, Vol. 25 No. 1, Juli 2007: $29-42$.

Frankema, E., 2010. The Colonial Roots of Land Inequality: Geography, Factor Endowments, or Institutions? Economic History Review, 63, 2 (2010), pages. 418-451.

Geertz, C., 1968. Agricultural Involution: The Process of Ecological Change in Indonesia. Third Printing. California: University of California Press.

Gedara, et al. 2012. Factors Affecting Technical Efficiency of Rice Farmers in Village Reservoir Irrigation Systems of Sri Lanka. Journal of Agricultural Economics. Volume 63, Issue 3, pages 627-638.

Harriss, J., 2013. Does 'Landlordism' Still Matter? Reflections On Agrarian Change In India. Journal of Agrarian Change, Vol. 13 No. 3, July 2013, Pages. 351-364.

Hayami, Y. dan M. Kikuchi, 1981. Pertanian Asia Tenggara di Persimpangan Jalan. Jakarta: LP3ES.

Jena, P.R. dan U. Greote, 2010. Changing Institutions to Protect Regional Heritage: A Case for Geographical Indications in the Indian Agrifood Sector. Development Policy Review. March 2010. Volume 28, Issue 2_pages 217-236.

Mosher, A.T., 1991. Menggerakkan dan Membangun Pertanian: Syarat-Syarat Pokok Pembangunan dan Modernisasi. Jakarta: CV Yasaguna.

North, D.C., 1990. Institution, Institutional Change and Economic Performance. Cambridge: Cambridge University Press.

Popkin, S., 1986. Petani Rasional. Jakarta: Yayasan Padamu Negeri.

Rachman, et.al., 2005. Ekonomi Kelembagaan Sistem Usahatani Padi Di Indonesia. Bogor: Pusat Penelitian Sosial Ekonomi Pertanian.

Saptana, et.al., 2003. Transformasi Kelembagaan Tradisional Untuk Menunjang Ekonomi Kerakyatan di Pedesaan: Studi Kasus Propinsi Bali dan Bengkulu. Bogor: Pusat Penelitian dan Pengembangan Sosial Ekonomi Pertanian, Badan Penelitian dan Pengembangan Pertanian, DEPTAN.

Scoones, I. dan J. Thompson, 2011. The Politics of Seed in Africa's Green Revolution: Alternative Narratives and Competing Pathways. IDS Bulletin, Volume 42 Number 4 July 2011.

Scott, J. C., 1981. Moral Ekonomi Petani: Pergolakan dan Subsistensi di Asia Tenggara. Jakarta: LP3ES.

Searle, J., 2001. Rationality in Action. A Bradford Book. Cambridge: The MIT Press.

Srang-iam, 2013. Decontextualized Knowledge, Situated Politics: The New ScientificLocal Politics of Rice Genetic Resources in Thailand. Development and Change, Volume 44, Issue 1, pages 1-27. 
Suradisastra, et.al, 2007. Status dan Arah Pengembangan Kelembagaan Petani. Prosiding Kinerja Dan Prospek Pembangunan Pertanian Indonesia. ISBN: 978-979-3566-59-7.

Syahyuti. 2010. Lembaga dan Organisasi Petani dalam Pengaruh Negara dan Pasar. Majalah Forum Agro Ekonomi Vol. 28 No.1.

Weber, M., 1958. The Rational And Sosial Foundation Of Music. Southern Illinois University Press . New York.

Weber, M. 1992. The Protestant Ethic and the Spirit of Capitalism. Retrieved from http://books.google.com/books?id=h_OvkrxWzFUC\& pgis=1.

Welker, Marina. 2012. The Green Revolution's Ghost: Unruly subjects of participatory development in rural Indonesia. American Ethnologist. Volume 39, Issue 2, pages 389-406.

Wolf, E.R. 1985. Petani: Suatu Tinjauan Antropologi. Penerbit CV. Rajawali, Jakarta.

Yunus, A., 2017. Rasionalitas dan Kewirausahaan Petani dalam Merespons Perubahan Sosio-Teknis dan Kelembagaan Usahatani Padi. Disertasi, Program Pasca Sarjana Universitas Hasanuddin.

Yunus, A., D. Salman, Demmallino, E.B., Viantika, N.M., 2016. Sociotechnical Change and Institutional Adjustment in Paddy Rice Farming During Post Green Revolution in Indonesia. IJAS, Vol.2, Issue 2. 